\title{
Control of Cellular Aging, Tissue Function, and Cancer by p53 Downstream of Telomeres
}

\author{
Caitlin M. Roake ${ }^{1,2}$ and Steven E. Artandi ${ }^{1,2,3}$ \\ ${ }^{1}$ Department of Medicine, Stanford University School of Medicine, Stanford, California 94305 \\ ${ }^{2}$ Cancer Biology Program, Stanford University School of Medicine, Stanford, California 94305 \\ ${ }^{3}$ Department of Biochemistry, Stanford University School of Medicine, Stanford, California 94305 \\ Correspondence: sartandi@stanford.edu
}

Telomeres, the nucleoprotein complex at the ends of eukaryotic chromosomes, perform an essential cellular role in part by preventing the chromosomal end from initiating a DNAdamage response. This function of telomeres can be compromised as telomeres erode either as a consequence of cell division in culture or as a normal part of cellular ageing in proliferative tissues. Telomere dysfunction in this context leads to DNA-damage signaling and activation of the tumor-suppressor protein p53, which then can prompt either cellular senescence or apoptosis. By culling cells with dysfunctional telomeres, p53 plays a critical role in protecting tissues against the effects of critically short telomeres. However, as telomere dysfunction worsens, p53 likely exacerbates short telomere-driven tissue failure diseases, including pulmonary fibrosis, aplastic anemia, and liver cirrhosis. In cells lacking p53, unchecked telomere shortening drives chromosomal end-to-end fusions and cycles of chromosome fusion-bridge-breakage. Incipient cancer cells confronting these telomere barriers must disable p53 signaling to avoid senescence and eventually up-regulate telomerase to achieve cellular immortality. The recent findings of highly recurrent activating mutations in the promoter for the telomerase reverse transcriptase (TERT) gene in diverse human cancers, together with the widespread mutations in p53 in cancer, provide support for the idea that circumvention of a telomere-p53 checkpoint is essential for malignant progression in human cancer.

$T^{\mathrm{h}}$ he inability of primary human cells to be cultured indefinitely provided the first suggestion for an inherent limit placed on cell division. This behavior of normal cells directly isolated from tissues contrasted with the indefinite proliferation of cancer cells in culture. Although the underlying molecular basis for this difference between normal cells and cancer cells remained elusive for more than 20 years, we now know that it is explained by a differential ability to maintain telomeres, the nucleoprotein caps that protect chromosome ends. The vast majority of human cancer cells express telomerase, the enzyme that elongates telomeres, whereas the primary cell culture models lacked telomerase expression. The roadblocks preventing cell growth in primary cells included two different responses-replicative senescence and

Editors: Guillermina Lozano and Arnold J. Levine

Additional Perspectives on The p53 Protein available at www.perspectivesinmedicine.org

Copyright (C) 2017 Cold Spring Harbor Laboratory Press; all rights reserved; doi: 10.1101/cshperspect.a026088

Cite this article as Cold Spring Harb Perspect Med 2017;7:a026088 
C.M. Roake and S.E. Artandi

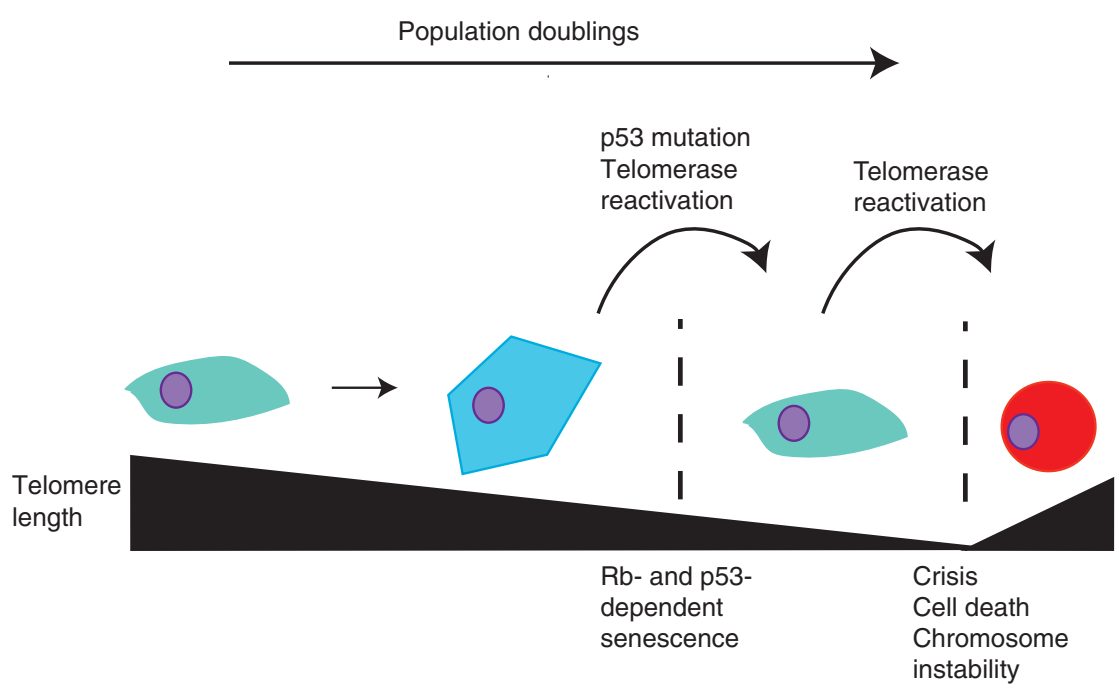

Figure 1. Telomere shortening in cell culture limits the proliferation of primary cells. After a defined number of population doublings in culture, short telomeres in fibroblasts trigger a DNA-damage response that acts through p53 to cause cellular senescence and a halt on proliferation. To proceed past senescence, cells must inactivate p53 and $\mathrm{Rb}$, or up-regulate telomerase to achieve telomere maintenance. Once cells escape senescence, continued telomere shortening will lead to a period of genomic instability termed crisis, which is characterized by cell death and chromosomal instability. Expression of telomerase will stabilize the genome and allow continued proliferation of the culture.

crisis (Fig. 1). The senescence barrier is enforced by two key tumor-suppressor pathways- $-\mathrm{p} 53$ and $\mathrm{Rb}$. These barriers are not only relevant in limiting cell proliferation in culture, but are critically important in human tissues and in human carcinogenesis.

In mouse models of telomerase deficiency, p53 was identified as a key pathway governing the widespread defects in proliferative tissues. Elimination of p53 in these telomerase-deficient models partially rescued the effects of dysfunctional telomeres, providing a mechanistic link connecting telomeres and p53 in mammalian tissues. Many human diseases are characterized by a failure of tissue maintenance, leading to severe organ damage and a failure of the primary function of the organ in question. The telomere biology disorders include the genetic disease dyskeratosis congenita (DC), a multisystemic disorder likely attributable to stem-cell dysfunction. Mutations in the telomerase pathway are now known to cause many such tissue failure phenotypes, including pulmonary fibrosis, aplastic anemia, and liver cirrhosis. These se- vere consequences of impaired telomere maintenance represent an in vivo correlate of the replicative senescence and crisis barriers to cell proliferation described in culture and first seen in telomerase knockout mice. The connection between telomeres and p53 in cell culture and in telomerase knockout mice suggested an important link to cancer development. The p53dependent response to dysfunctional telomeres serves as a strong brake to tumor development in mouse models. The profound telomere shortening seen during the course of human carcinogenesis strongly suggests that a similar process of telomere dysfunction activating p53 curtails human cancer development. This hypothesis was recently strengthened by the discovery of highly recurrent mutations in the promoter of the telomerase reverse transcriptase (TERT) gene. These mutations represent definitive genetic evidence that reestablishing telomere maintenance is rate-limiting for tumor progression, enabling aspiring cancers to overcome barriers to tumor growth dictated by the telomerep53 checkpoint. 


\section{MAMMALIAN TELOMERES ARE NUCLEOPROTEIN COMPLEXES THAT PROTECT CHROMOSOME ENDS}

Telomeres are comprised of tracts of G-rich nucleotide repeats that serve as binding sites for a protein complex termed shelterin (Fig. 2). In vertebrates, telomeres are composed of the sequence TTAGGG, and include a double-stranded tract of repeats many kilobases long and an obligate single-stranded $3^{\prime}$ overhang, measuring a few hundred nucleotides (Palm and de Lange 2008). The single-stranded overhang can fold back on the double-stranded telomere in a lariat structure termed the T-loop, which serves to sequester the chromosome terminus, which hybridizes to internal sequences creating a small displacement loop, or D-loop (Griffith et al. 1999; Doksani et al. 2013). Double-stranded telomere sequences are bound directly by two sequence-specific DNA-binding proteins, TRF1 and TRF2, which in turn interact with a larger number of proteins. TRF2 is critical for telomere end protection and contributes to formation of the T-loop conformation. Disruption of TRF2 through overexpression of a dominantnegative form or through deletion in TRF2 knockout mouse embryo fibroblasts leads to loss of the protective capped structure, characterized by processing of the $3^{\prime}$ overhang and ligation of chromosome ends (van Steensel et al. 1998; Celli and de Lange 2005). TRF1 can act to modulate telomere length, but it serves a critical role in facilitating DNA replication through the telomere repeats, which act as fragile DNA sites (van Steensel and de Lange 1997; Smogorzewska et al. 2000; Martinez et al. 2009; Sfeir et al. 2009).

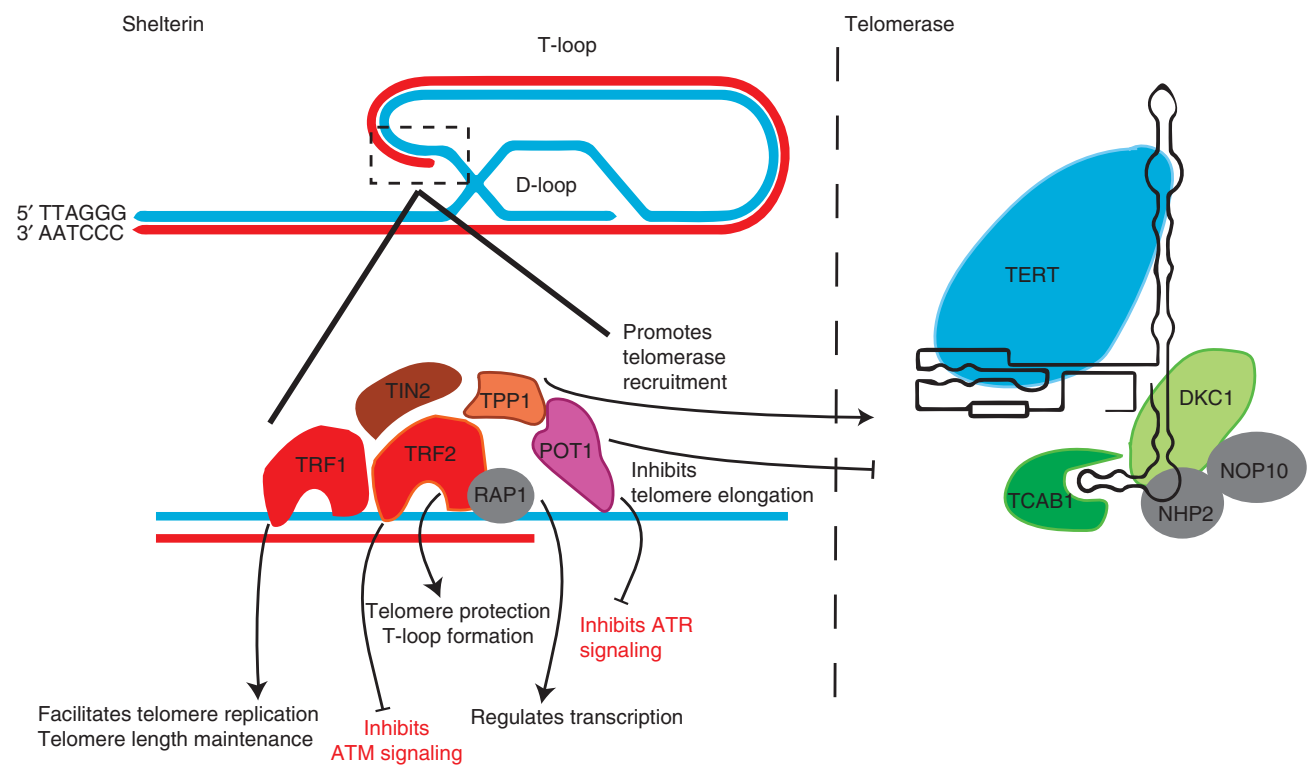

Figure 2. Shelterin, the telomere-binding complex, protects chromosome ends and controls telomerase function. Telomeric DNA is bound by the double-stranded DNA-binding proteins TRF1 and TRF2 and by the singlestranded DNA-binding protein Pot1. Rap1 binds to TRF2 and functions as a transcriptional regulator. TIN2 nucleates the complex by connecting TRF1 and TRF2 to the Tpp1/Pot1 subcomplex. Each component of shelterin serves a specialized function in telomere maintenance, with TRF2 and Pot1 involved in suppression of DNA-damage signaling, and TRF1 involved in facilitating replication through difficult to replicate telomeric sequences. Telomerase is recruited to the complex through its interaction with Tpp1; once at the telomere, its action is negatively regulated by Potl. Telomerase is a ribonucleoprotein composed of a noncoding RNATERC that serves as a scaffold for protein components TERT, TCAB, dyskerin, NOP10, and NHP2. Dyskerin and its associated proteins promote TERC biogenesis and stability, whereas TCAB facilitates trafficking of telomerase to the telomere. TERT is the catalytic subunit and TERC encodes the template for reverse transcription. 
TRF1 and TRF2 each interact with a common factor TIN2 (Kim et al. 1999), which nucleates a six-member complex, termed shelterin, which also includes RAP1, POT1, and TPP1 (de Lange 2005). RAP1 is a TRF2-interacting factor, related to Rap1p, a critical telomere-binding protein in Saccharomyces cerevisiae ( $\mathrm{Li}$ et al. 2000). Unlike yeast Rap1p, mammalian RAP1 does not bind telomeric DNA directly, but is instead recruited to telomeres through its interaction with TRF2. Deletion of Rap1 in human cells reveals a role for Rap1 in telomere recombination and transcriptional regulation, but not in telomere end protection or telomere length maintenance (Sfeir et al. 2010; Yeung et al. 2013; Kabir et al. 2014). TIN2 also interacts with the subcomplex of shelterin that binds the singlestranded overhang: TPP1 and POT1, two oligosaccharide-binding (OB)-fold-containing proteins (Baumann and Cech 2001; Liu et al. 2004; Ye et al. 2004). POT1 directly binds the singlestranded telomere sequences and interacts directly with TPP1. POT1 and TPP1 serve a role in protecting the single-stranded portion of the telomere, because loss of POT1 impairs telomere capping (Hockemeyer et al. 2005, 2006; Wu et al. 2006; Hockemeyer et al. 2007). In addition, POT1 and TPP1 can control telomerase action at telomeres. Overexpression of POT1 leads to telomere shortening by inhibiting telomerase action at the telomere (Loayza and de Lange 2003). In contrast, POT1 and TPP1 in vitro serve as potent enhancers of telomerase processivity (Wang et al. 2007; Xin et al. 2007). TPP1 represents the key shelterin component governing recruitment of telomerase to telomeres. Knockdown of either TPP1, or the protein needed for tethering TPP1 to telomeres, TIN2, impairs the ability of telomerase to be recruited to telomeres (Abreu et al. 2010). TPP1 was shown to be the critical subunit governing recruitment, and this activity is restricted to the oligonucleotide/OB domain of TPP1, which is sufficient for binding telomerase when tethered to a nontelomeric locus. Disruption of the TPP1-TERT interaction blocks the ability of telomerase to be maintained by telomeres, leading to eventual cell death (Nandakumar et al. 2012; Zhong et al. 2012; Sexton et al. 2014).

\section{REPLICATIVE SENESCENCE: CONNECTING TELOMERES TO p53 IN CULTURED HUMAN CELLS}

The observation by Leonard Hayflick that primary human fibroblasts can only undergo a predetermined number of cell divisions indicated the presence of an intrinsic counting mechanism governing cell fate (Fig. 1) (Hayflick and Moorhead 1961). After 60-80 divisions, fibroblasts encountered replicative senescence, a permanent growth arrest in the $G_{1}$ phase of the cell cycle. The senescence barrier could be bypassed, but only temporarily, by expression of the SV40 early region, leading to a new state termed crisis. At crisis, the ultimate role of telomeres in preventing chromosome end recombination is revealed. Rather than cell-cycle arrest, crisis is characterized by high rates of cell death and rampant chromosomal instability, including endto-end chromosome fusions (Counter et al. 1992). Dissection of the requirements for bypassing replicative senescence led to the insight that neutralization of both $\mathrm{p} 53$ and $\mathrm{Rb}$ pathways was required to reach crisis. Pathway inactivation using viral oncoproteins, including adenovirus E1A and E1B, human papilloma virus E6 and E7, or SV40 large T alone, enabled senescence to be circumvented (Shay et al. 1991). Similarly, antisense RNAs directed against both p53 and $\mathrm{Rb}$ allowed direct entry to crisis in human cells (Hara et al. 1991). The requirement for p53 in enforcing replicative senescence implied that downstream transcriptional targets of p53 were similarly required. The cyclin-dependent kinase inhibitor p21 (CIP1/WAF1) is a prominent transcriptional target of $\mathrm{p} 53$, is induced by DNA damage and other stresses, and contributes to p53-dependent cell-cycle arrest. Inactivation of p21 using homologous recombination in primary human cells bypassed senescence and enabled additional cell divisions eventually leading to crisis (Brown et al. 1997). Thus, p53 and Rb pathways were linked to the barriers controlling cellular life span of human cells in culture, with provocative implications for how telomeres and p53 connect in limiting human cancer.

Speculation that telomere shortening may represent the counting mechanism explaining 
the protracted delay in triggering replicative senescence responses (Watson 1972; Olovnikov 1973) could not be tested until telomeres were molecularly defined. The discovery of the first telomere sequence (Blackburn and Gall 1978) and the discovery of the enzyme telomerase in the ciliate Tetrahymena (Greider and Blackburn 1985) enabled such hypotheses to be tested. In Tetrahymena or in S. cerevisiae, interfering with telomerase function triggered senescence in these organisms, providing a key mechanistic link between telomeres and senescence in unicellular eukaryotes (Yu et al. 1990; Lundblad and Blackburn 1993). Identification of TTAGGG repeats at telomeres in vertebrates allowed human telomere length to be queried experimentally. Examination of telomere lengths in cultured fibroblasts by Southern blot revealed that, indeed, telomeres shortened with cell divisions as primary cells approached senescence (Harley et al. 1990). These findings showed that telomere shortening correlated with senescence, but did not establish short telomeres as the root cause of the senescence arrest. The cloning of human TERT allowed telomerase activity to be manipulated in human cells for the first time (Lingner et al. 1997; Meyerson et al. 1997; Nakamura et al. 1997).

Stable overexpression of TERT in human fibroblasts reconstituted telomerase activity, indicating that TERT was the only subunit limiting telomerase expression in primary human cells. Re-expression of telomerase was sufficient to elongate telomeres, bypass senescence, and immortalize cells, proving that telomere shortening represented the counting mechanism triggering senescence at the Hayflick limit (Fig. 1) (Bodnar et al. 1998). Importantly, these findings also established that, as long as telomeres are maintained efficiently, the p53 and Rb checkpoints are not triggered, indicating that there are no other stressors in this context to activate p53 and impair cell proliferation.

\section{INTERPLAY BETWEEN TELOMERES AND p53 IN VERTEBRATE ANIMAL MODELS}

Cloning of the murine components of the catalytic core of the telomerase enzyme, TERT, and the telomerase RNA component, TERC, allowed the functions of telomerase and telomeres to be tested in a living mammal. Inbred strains of laboratory mice have much longer telomeres than humans (40-80 kb vs. 5-15 kb) (Kipling and Cooke 1990). As a result, loss of telomerase activity in telomerase knockout mice showed no effect; first-generation $\left(\mathrm{G}_{1}\right)$ telomerase knockout mice were viable and apparently normal because they retained very long telomeres. However, as telomerase-deficient mice were generated by intercrossing $G_{1}$ knockout mice to create generation $2\left(\mathrm{G}_{2}\right)$ knockout mice, and this process continued for many generations, telomeres shortened progressively. Eventually, chromosomal end-to-end fusions occurred as telomere sequences were lost from a subset of ends (Blasco et al. 1997). Correlating with the onset of telomere dysfunction in G4-G6 telomerase knockout mice, animals developed defects in many highly proliferative tissues. Most prominent among the phenotypes were infertility and loss of the male germline, intestinal dysfunction, and lymphocyte dysfunction (Lee et al. 1998; Wong et al. 2000). Infertility in males and females prevented the propagation of telomerase-deficient mouse strains beyond the sixth generation.

The dominant response to telomere dysfunction in failing tissues of telomerase knockout mice was an apoptotic one. Late-generation TERC $^{-/-}$mice showed very high levels of apoptosis in multiple organs, including testis, lymphoid tissue, and intestinal epithelium, coincident with stabilization and activation of p53 (Chin et al. 1999). These phenotypes were largely rescued in $\mathrm{TERC}^{-/-} \mathrm{p} 53^{-/-}$animals. Cellularity of the testis was significantly improved, and apoptosis was correspondingly rescued, in G6 TERC $^{-/-} \mathrm{p} 53^{-/-}$compared with G6 TERC $^{-/-}{\mathrm{p} 53^{+/+}}^{+1}$ littermates. Telomere short-

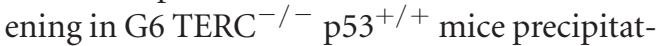
ed a premature aging phenotype, characterized by kyphosis, hair graying, hair loss, villous atrophy in the intestine, and impaired systemic stress responses (Herrera et al. 1999; Rudolph et al. 1999). These results indicate that p53 serves a critical function in responding to dysfunctional telomeres and in mediating the adverse apoptotic phenotypes in vivo, just as it 
C.M. Roake and S.E. Artandi

serves to enforce replicative senescence in cultured human fibroblasts (Fig. 1). These findings also provided a potential link between cellular aging and aging of the whole organism, with p53 a critical mediator of both phenotypes.

Other vertebrate model organisms have proved to be useful in studying telomerase function as well. Because of their shorter telomeres, zebrafish lacking the telomerase catalytic subunit TERT exhibit shorter life spans within the first generation and show infertility, intestinal atrophy, and loss of skeletal muscle (Henriques et al. 2013). Proliferative defects were rescued by p53 loss in TERT $^{-/-}$p53 ${ }^{-/-}$zebrafish, indicating a conserved role for $\mathrm{p} 53$ in responding to telomere dysfunction in vertebrates. The African turquoise kilifish is the shortest lived vertebrate grown in a laboratory setting, making it ideal for the study of aging related genes; killifish lacking TERTexhibit greatly decreased male fertility and fail to produce viable offspring (Harel et al. 2015). Studies using these organisms have only just begun, but may soon prove to be an efficient and cost-effective way to study the role of telomerase in vertebrate aging and the role of p53 and other checkpoints downstream of telomere uncapping.

\section{LOCAL DNA DAMAGE AT UNCAPPED TELOMERES PROPAGATES SIGNALS THAT ACTIVATE p53}

As a subset of telomeres in culture or in vivo approach a critically short length, telomere structure or conformation is altered is such a way that a DNA-damage response can no longer be suppressed. Such critically short telomeresalso called uncapped telomeres - trigger DNAdamage signaling similar to that caused by double-stranded DNA breaks (Fig. 3). Senescent human fibroblasts show a number of telomeric foci that contain phosphorylated $\mathrm{H} 2 \mathrm{AX}$ and 53BP1, hallmarks of double-stranded breaks (d'Adda di Fagagna et al. 2003; Takai et al. 2003). These damaged telomeres are termed telomere dysfunction-induced foci (TIFs). This DNA-damage response can be recapitulated by inhibiting TRF2 function, or the function of other shel-

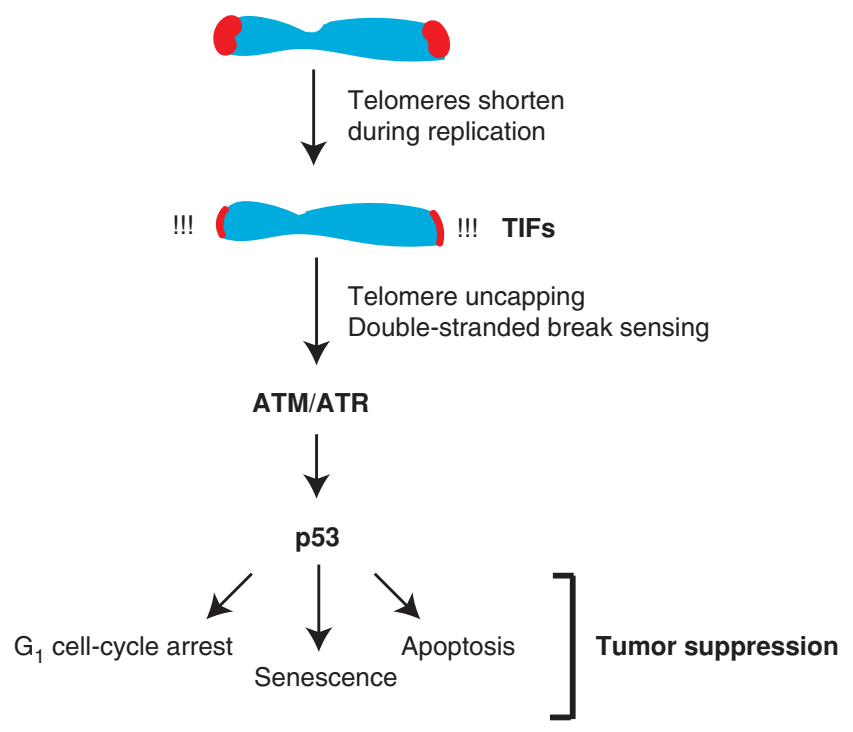

Figure 3. Pathways connecting telomeres and p53. Telomeres shorten with aging or with extended passage in culture, leading to eventual telomere uncapping. Uncapped telomeres lose their protective function, and telomere-dysfunction-induced foci, or TIFs, composed of DNA-damage proteins, are recruited to uncapped telomeres. Dysfunction telomeres can signal through the ATM and ATR kinases to phosphorylate p53. Phosphorylation stabilizes $\mathrm{p} 53$ by inhibiting its interaction with MDM2, and p53 then transcriptionally up-regulates target genes mediating $\mathrm{G}_{1}$ checkpoint arrest, senescence, and apoptosis. 
terin components, yielding an immediate DNAdamage response at acutely uncapped telomeres. For example, loss of TRF2 causes the appearance of DNA-damage foci at telomeres in an ATM-dependent fashion, resulting in the phosphorylation of the Chk2 kinase (Denchi and de Lange 2007). Mouse telomeres contain two paralogs of the human POT1 protein, POT1a, and POT1b. Conditional models using MEFs revealed that both POT1a and POT1b are required to suppress DNA damage at telomeres (Hockemeyer et al. 2006). Loss of POT1a, in particular, results in ATR activation and phosphorylation of both Chk1 and Chk2 (Wu et al. 2006; Denchi and de Lange 2007). These genetic studies led to an attractive model in which the double-stranded telomere complex (TRF2) and the complex that binds the single-stranded overhang (POT1 and TPP1) block signaling from ATM and ATR, respectively (Figs. 2 and 3). At long telomeres, the abundance of shelterin represses the activities of ATM and ATR, but as telomeres shorten the diminished loading of TRF2 and POT1 will allow de-repression of ATM and ATR and trigger the p53 response.

In contrast to total telomeric deprotection from complete TRF2 loss, telomeric deprotection at replicative senescence or in cell cultures with partially depleted TRF2 results in a differential double-stranded break response without phosphorylation of Chk2 and induction of the $\mathrm{G}_{2} / \mathrm{M}$ checkpoint; damaged telomeres are allowed to pass through mitosis and cause $G_{1}$ growth arrest in daughter cells (Cesare et al. 2013). Downstream of this signaling cascade, the activation of ATM kinase leads directly to p53 phosphorylation, as well as to the phosphorylation of Chk2 checkpoint kinase, which triggers additional modifications on p53 (Fig. 2). These posttranslational modifications to $\mathrm{p} 53$ promote displacement of MDM2 and cause p53 stabilization and activation.

\section{TELOMERE SHORTENING INHIBITS CARCINOGENESIS IN MODELS WITH AN INTACT p53 PATHWAY}

Because telomerase is expressed in $90 \%$ of human cancers (Kim et al. 1994) and is required for cellular immortalization in primary human cells, it was proposed that telomerase is required for carcinogenesis. This idea was tested in vivo in telomerase knockout mouse strains either treated with carcinogens to induce cancer or when studied on tumor-prone backgrounds lacking specific tumor-suppressor genes. Mice with deletions in the INK4A/ARF locus are susceptible to mesenchymal and lymphoid tumors. The INK4A/ARF locus codes for two tumor suppressors, p16 ${ }^{\mathrm{INK} 4 \mathrm{a}}$ and P19ARF, each expressed from a unique first exon spliced into a common second exon in unique reading frames. Deletion of the second exon results in loss of both gene products and a predisposition in mice to fibrosarcomas and lymphomas (Serrano et al. 1996; Kamijo et al. 1997). G5 TERC ${ }^{-/-}$mice lacking exon 2 of the locus developed tumors at half the rate of controls (Greenberg et al. 1999; Khoo et al. 2007). Although P19ARF serves a critical role in the p53 pathway downstream of aberrant oncogene signals, inactivation of P19ARF preserves the DNA damage arm of the p53 pathway. These data showed that, indeed, telomere dysfunction blocks tumor formation in a setting of intact DNA-damage signaling (Fig. 3).

Multiple additional lines of evidence similarly showed a decreased frequency of epithelial neoplasia in mice with short telomeres. Skin treatment with 7,12-dimethybenz(a)anthracene (DMBA) and promotion with 12-O-tetradecanoylphorbol 13-acetate (TPA) leads to efficient establishment of papillomas in mice coincident with activation of H-RAS. In this model, treatment of G5 $\mathrm{TERC}^{-/-}$mice with DMBA/TPA led to a 20 -fold lower rate of papilloma development than in WT mice and a 16-fold lower rate than in $\mathrm{G}_{1}$ TERC $^{-/-}$animals, suggesting that, in this context, short telomeres are protective against carcinogenesis (Gonzalez-Suarez et al. 2000). To investigate the effects of telomere dysfunction on intestinal adenoma formation, telomerase knockout mice were crossed with the $\mathrm{APC}^{\mathrm{min}}$ strain, in which a mutation in the APC gene promotes numerous intestinal polyps. $\mathrm{APC}^{\mathrm{min} /+} \mathrm{G} 4 \mathrm{TERC}^{-/-}$mice showed a much lower rate of adenoma formation than wild-type controls. Interestingly, adenomas from these mice showed overexpression of p53 and an 
increased amount of apoptosis (Rudolph et al. 2001). There is also evidence that short telomeres limit cancer development in vivo by inducing senescence. B-cell lymphomas were significantly suppressed in $\mathrm{E} \mu \mathrm{Myc}^{+}$G5-G6 TERC $^{-/-}$mice through induction of p53-dependent senescence (Feldser and Greider 2007). A mutant in p53, R172P, which has lost the ability to induce apoptosis but retains the ability to enforce cell-cycle arrest and senescence, has been studied in this context. Tumorigenesis was suppressed in mice with telomere dysfunction and the $\mathrm{p} 53-\mathrm{R} 172 \mathrm{P}$ allele, indicating the importance of p53-enforced cell-cycle arrest in suppressing telomere uncapping responses (Feldser and Greider 2007). These experiments revealed that telomere dysfunction compromised tumor development in part through activation of p53, providing a link between the p53-dependent responses seen in cultured human cells and tumor suppression in vivo.

\section{DYSFUNCTIONAL TELOMERES IN THE SETTING OF IMPAIRED p53 RESPONSES PREDISPOSE TO TRANSLOCATIONS, EPITHELIAL CANCERS, AND ANEUPLOIDY}

Human cell culture studies showed that loss of p53 overcame replicative senescence and enabled entry into crisis, which was interpreted as a second barrier to cancer formation (Fig. 1). Based on these findings, we might have expected that inactivation of p53 in mice with short telomeres would either remove the barrier to tumor progression imposed by dysfunctional telomeres, enabling cancer to develop unhindered, or leave cancer development severely impaired, just as crisis in culture induces cell death through a p53-independent mechanism. Instead of either of these possibilities, cancer formation was accelerated and shifted to a new tumor type. Surprisingly, in the context of p53 loss, mice with shortened telomeres developed cancer more rapidly and become primed for the development of carcinomas. Although p53 $3^{+-}$ mice typically develop lymphoid and mesenchymal lesions, late-generation TERC $^{-/-}$ p53 $3^{+/-}$mice acquired epithelial cancers such as cancers of the breast, GI tract, and skin (Artandi et al. 2000).

How is it that telomere shortening promotes rather than inhibits tumor formation in a p53mutant background? In telomerase-deficient cells in culture and in neoplasias from late-generation TERC $\mathrm{p} 53^{+/-}$mice, telomere shortening leads to formation of chromosomal fusions, and anaphase bridges. Activation of p53 in this case would normally lead to cellular arrest or apoptosis and impaired tumor development. Without p53, however, these fused chromosomes promoted more widespread chromosomal instability through cycles of chromosome fusion-bridge-breakage (Fig. 4). Specifically, telomere dysfunction promoted nonreciprocal translocations, a cytogenetic hallmark of epithelial tumors (Artandi et al. 2000). Carcinomas

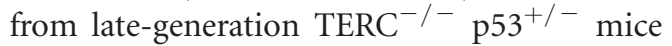
showed formation of translocations between nonhomologous chromosomes, as well as widespread regional gene copy number changes by comparative genome hybridization (O'Hagan et al. 2002). It is these changes in gene copy number-gains of oncogenes and losses of tumor-suppressor genes - that likely drive tumorigenesis in this context (Fig. 4). The role of telomere dysfunction in promoting translocations and tumorigenesis emerged as a consistent theme. In cultured human cells, disrupting telomere-capping function through TRF2 inactivation also drove formation of nonreciprocal translocations, indicating that these rearrangements can be catalyzed either through progressive telomere shortening or through immediate telomere uncapping through shelterin disruption (Smogorzewska et al. 2002). Furthermore, time-lapse imaging of cells in which TRF2 has been inactivated revealed the formation of anaphase bridges during mitosis, which persist into the next interphase. After bridge resolution, surviving cells show genomic rearrangements on multiple chromosomes (chromothripsis), as well as clusters of point mutations (also known as kaetegis), which correspond to genomic regions near genomic breakpoints. These findings provide more evidence that telomere dysfunction can fuel the types of genomic aberrations commonly seen in cancer (Maciejowski 


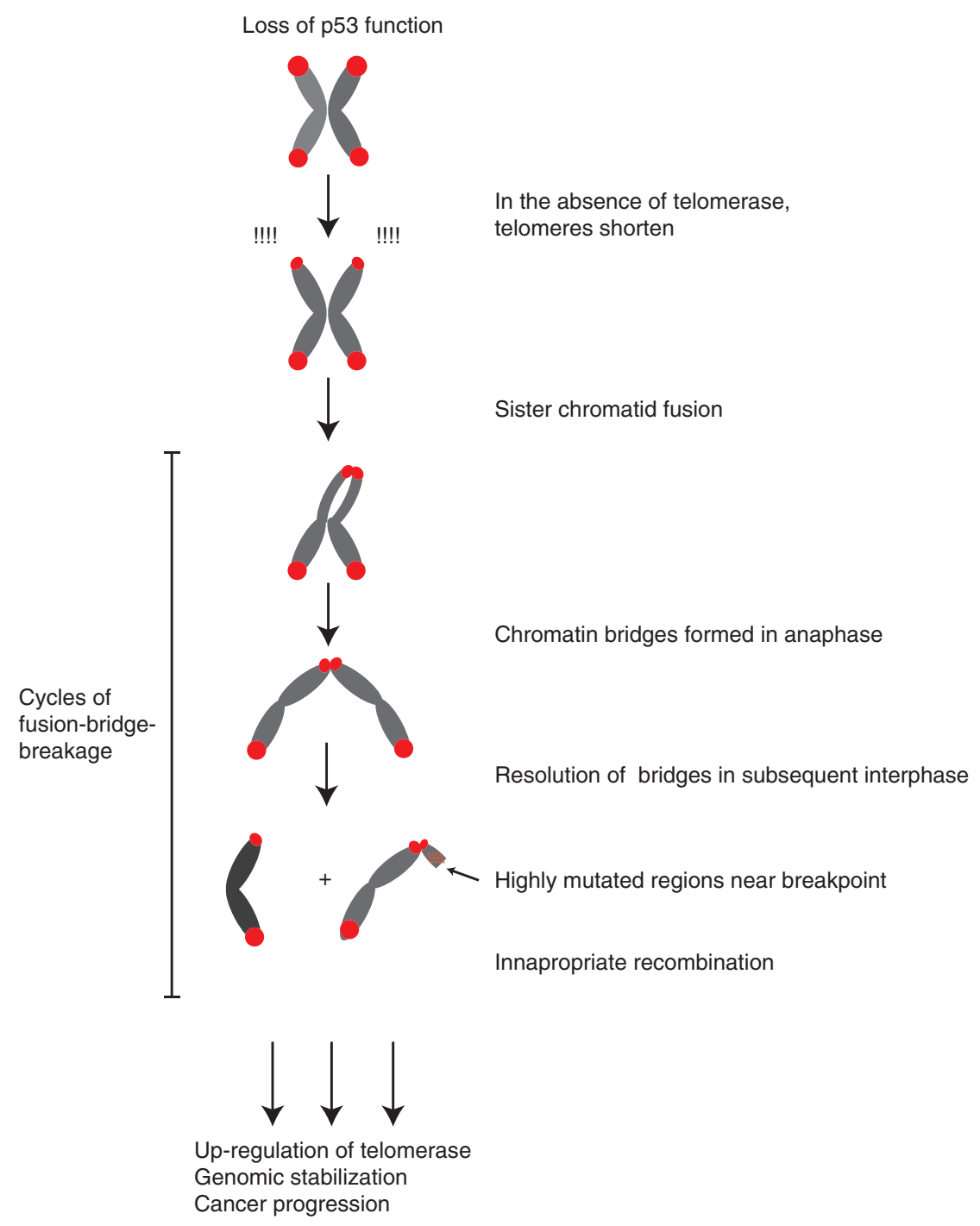

Figure 4. Telomere dysfunction promotes cancer through cycles of chromosome fusion-bridge-breakage. In a p53-null background, telomeres are able to shorten over repeated cell divisions without causing senescence. After a critical length is reached, telomere uncapping occurs leading to covalent ligation of sister chromatids in this example. During mitosis, chromosome migration to opposite spindle poles results in chromosomal breakage. The broken chromosome is now susceptible to recombination with other chromosomes, causing nonreciprocal translocations and leading to copy number alterations. After many cycles, up-regulation of telomerase by malignant cells would allow stabilization of the karyotype, and the tumor with a newly altered genome would be able to proceed in its evolution.

et al. 2015). Along these lines, mice mutant for the telomere-binding protein TPP1 develop adrenocortical dysplasia (ACD) and other developmental abnormalities through telomere uncapping and these phenotypes are largely rescued by p53 deficiency (Keegan et al. 2005; Vlan- gos et al. 2009). Similar to the G5-G6 TERC ${ }^{-/-}$ $\mathrm{p} 53^{+/-}$model, TPP $1^{\text {acd/acd }} \mathrm{p} 53^{+/-}$mice are highly prone to epithelial carcinomas of the skin, and these cancers possess nonreciprocal translocations (Else and Hammer 2009). These data established an important role for dysfunc- 
tional telomeres in catalyzing the formation of nonreciprocal translocations and driving carcinoma formation through gene copy number alterations.

Dysfunctional telomeres can also promote tumorigenesis through a mechanism distinct from cycles of fusion-bridge-breakage. Inactivation of POT1, the protein that binds the single-stranded overhang, leads to deprotection at telomeres and TIF formation (Hockemeyer et al. 2006; Wu et al. 2006). The prolonged DNA-damage response emanating from telomeres in POT1-deficient p53-deficient mouse embryo fibroblasts leads to a prolonged arrest in the $G_{2}$ phase of the cell cycle. Eventually, cells progress through this barrier without entering mitosis, resulting in endoreduplication and tetraploidy (Davoli et al. 2010). This tetraploidization creates a perfect substrate for transformation because it allows for development of widespread aneuploidy. Indeed, mouse cells with these features show an increased rate of cellular transformation (Davoli and de Lange 2012). This is significant because a substantial proportion of human tumors have very high numbers of chromosomes, ranging from hypertriploid to subtetraploid. It is possible that these tumors arose from an initial tetraploid cell that then underwent chromosome loss. These findings reveal another means by which p53 can disallow transformation, by preventing cells with persistent telomere damage from promoting tetraploidization and aneuploidy.

\section{MUTATIONS IN THE TELOMERASE PATHWAY CAUSE DC AND RELATED TELOMERE BIOLOGY DISORDERS}

The critical role of telomerase in preventing senescence, together with the numerous tissue defects seen in telomerase knockout mice suggested the possibility that disruptions of telomere maintenance could contribute to human disease. Inactivating mutations in telomerase genes were first linked to DC, a rare genetic disorder most commonly seen in children and young adults. In its classic form, DC is characterized by a clinical triad of epidermal features: skin hyper- and hypopigmentation, nail dystro- phy, and mucosal leukoplakia. DC is considered a bone marrow failure syndrome because aplastic anemia is one of the life-threatening phenotypes in the disease. DC is a multisystemic disease because patients are also prone to pulmonary disease and liver disease, and show a large number of other phenotypes, including hair loss and graying, cardiovascular disease, osteoporosis, and gastrointestinal disease. DC can now be considered one disease across a spectrum of telomere biology disorders (Armanios and Blackburn 2012). At one end of the spectrum of severity is Hoyeral-Hreidarsson $(\mathrm{HH})$ syndrome, which presents in infancy with cerebellar hypoplasia, bone marrow failure, and developmental delay (Knight et al. 1999). Classical DC often presents in early childhood or young adulthood. Many patients with germline mutations in telomerase genes present later in life and with more isolated phenotypes. Telomerase mutations underlie approximately $20 \%$ of familial idiopathic pulmonary fibrosis (Armanios et al. 2007). Five percent to $10 \%$ of aplastic anemia is also caused by telomerase mutations (Yamaguchi et al. 2003, 2005). Liver cirrhosis has also been attributed to telomerase mutations (Calado et al. 2011; Hartmann et al. 2011). It remains unclear how germline mutations in telomerase genes result in such variable phenotypes, including late presentations sometimes affecting only a single organ system, as in IPF. Undoubtedly, modifier genes and environmental factors contribute. Telomere length is a likely key variable, as DC inheritance shows genetic anticipation. DC can become more severe and present at an earlier age in the children of patients as telomeres shorten from generation to generation, just as in telomerase knockout mice (Vulliamy et al. 2004; Armanios et al. 2005).

The underlying pathophysiology of each of these syndromes relates to short telomeres and the attendant consequences of senescence and cell death seen in cultured human cells and in mouse models. As a result, telomere biology disorders are linked to mutations in genes involved in telomere homeostasis (Fig. 1). These diseases are transmitted with various modes of inheritance (Table 1). The mechanisms governing these disease states are diverse, each impact- 
Table 1. The genetic basis of dyskeratosis congenita and telomere biology diseases

\begin{tabular}{|c|c|c|c|c|}
\hline Inheritance & Gene & $\begin{array}{c}\text { Telomerase } \\
\text { pathway function }\end{array}$ & $\begin{array}{l}\text { Molecular mechanism } \\
\text { of disease }\end{array}$ & References \\
\hline X-linked & $D K C 1$ & TERC biogenesis & $\begin{array}{l}\text { Decreased TERC accumulation; } \\
\text { decreased telomerase activity }\end{array}$ & Mitchell et al. 1999 \\
\hline \multirow[t]{3}{*}{$\begin{array}{l}\text { Autosomal } \\
\text { dominant }\end{array}$} & TERT & Catalytic subunit & Decreased telomerase activity & $\begin{array}{l}\text { Armanios et al. 2005; } \\
\quad \text { Yamaguchi et al. } 2005\end{array}$ \\
\hline & TERC & $\begin{array}{l}\text { RNA template } \\
\text { subunit }\end{array}$ & Decreased telomerase activity & Vulliamy et al. 2001 \\
\hline & TINF2 & Shelterin protein & $\begin{array}{l}\text { Telomerase-independent } \\
\text { telomere shortening }\end{array}$ & Savage et al. 2008 \\
\hline \multirow[t]{4}{*}{$\begin{array}{r}\text { Autosomal } \\
\text { recessive }\end{array}$} & $\begin{array}{l}\text { NHP2, } \\
\quad \text { NOP10 }\end{array}$ & TERC biogenesis & $\begin{array}{l}\text { Decreased TERC accumulation; } \\
\text { decreased telomerase activity }\end{array}$ & $\begin{array}{l}\text { Walne et al. 2007; Vulliamy } \\
\text { et al. } 2008\end{array}$ \\
\hline & TCAB1 & $\begin{array}{l}\text { Telomerase } \\
\text { trafficking }\end{array}$ & $\begin{array}{l}\text { Decreased telomerase } \\
\text { recruitment }\end{array}$ & Zhong et al. 2011 \\
\hline & CTC1 & $\begin{array}{l}\text { Telomere } \\
\text { protection }\end{array}$ & Telomere uncapping & $\begin{array}{l}\text { Anderson et al. 2012; Chen } \\
\text { et al. } 2013\end{array}$ \\
\hline & $T P P 1$ & $\begin{array}{l}\text { Telomerase } \\
\text { trafficking }\end{array}$ & $\begin{array}{l}\text { Decreased telomerase } \\
\text { recruitment }\end{array}$ & Kocak et al. 2014 \\
\hline \multirow[t]{2}{*}{ Mixed AD/AR } & RTEL1 & Telomere helicase & Telomere loss & $\begin{array}{l}\text { Ballew et al. 2013; Vannier } \\
\text { et al. 2013; Walne et al. } \\
2013\end{array}$ \\
\hline & $P A R N$ & TERC biogenesis & $\begin{array}{r}\text { Decreased TERC accumulation; } \\
\text { decreased telomerase activity }\end{array}$ & $\begin{array}{l}\text { Dhanraj et al. 2015; Moon } \\
\text { et al. 2015; Stuart et al. } \\
2015 \text {. }\end{array}$ \\
\hline
\end{tabular}

ing on the ability of telomeres to be maintained. Mutations in the catalytic core of the enzyme, TERT or TERC, typically occur in one allele and act through haploinsufficiency to reduce enzyme activity (Vulliamy et al. 2001; Armanios et al. 2005; Yamaguchi et al. 2005). Mutations in dyskerin (DKC1), an RNA-binding protein that controls TERC biogenesis and stability, are $\mathrm{X}$-linked recessive and result in reduced TERC levels (Mitchell et al. 1999). Similarly, autosomal recessive mutations in the dyskerin-associated proteins, NHP2 and NOP10, reduce TERC levels (Walne et al. 2007; Vulliamy et al. 2008). TCAB1 is an unusual telomerase holoenzyme protein because it functions to control trafficking of the enzyme complex to Cajal bodies and to telomeres. Autosomal recessive mutations in TCAB1 cause mislocalization of telomerase to nucleoli (Venteicher et al. 2009; Zhong et al. 2011, 2012). Telomere-binding proteins can also be mutated in DC (Table 1). Mutations in TIN2 occur in a severe autosomal-dominant form of the disease that acts through as-yet un- clear mechanisms (Savage et al. 2008). Mutations in TPP1 can interfere specifically with telomerase recruitment to telomeres (Kocak et al. 2014). Coats plus disease is a rare disorder that at first glance seems unrelated to telomere biology syndromes. This disease is characterized by retinal telangiectasias, retinal exudates, brain leukodystrophy, and brain cysts. Some Coats plus patients also show phenotypic overlap with DC patients, and this syndrome is caused by mutations in CTC1, which forms a singlestranded DNA-binding complex together with STN1 and TEN1, important in DNA replication and replication of telomeres (Anderson et al. 2012; Chen et al. 2013). Telomere biology disorders are also caused by mutations in RTEL, a DNA helicase that serves to unwind D-loops and is important in DNA replication and homologous recombination. RTEL is mutated in $\mathrm{DC}$ where its role in unwinding T-loops is abrogated leading to telomere shortening (Ballew et al. 2013; Vannier et al. 2013; Walne et al. 2013). Most recently, mutations in PARN, 
a nuclease that removes polyA sequences from RNAs, have been reported to cause severe DC and IPF, by promoting TERC species with increased polyA tails (Dhanraj et al. 2015; Moon et al. 2015; Stuart et al. 2015). Thus, telomere biology disorders can arise through mutations in telomerase, telomere-binding proteins, and enzymes required for processing telomerase or telomere DNA sequences.

Telomerase mutations are associated not only with tissue defects, but also with a paradoxical increase in cancer. DC patients have a greatly increased cancer risk in the third and fourth decades of life, a rate that is 11-fold greater than age-matched controls. They are especially prone to epithelial cancers of the head and neck, myelodysplastic syndrome, and acute myeloid leukemia (Alter et al. 2009). This cancer-prone state occurs in the setting of short, dysfunctional telomeres and is likely mediated through a chromosomal instability mechanism as in telomerase-deficient p53-mutant mice, although this needs to be investigated further. The role of p53 in telomere biology syndromes also requires additional study. Based on studies in model systems, p53 likely contributes to tissue failure phenotypes in patients with telomere syndromes by culling stem cells from affected tissues. A recent mouse study showed that a nonsense mutation in p53 causing truncation and loss of the carboxy-terminal domain led to development of phenotypes resembling DC, including aplastic anemia, pulmonary fibrosis, and the epidermal triad of oral leukoplakia, nail dystrophy, and skin hyperpigmentation (Simeonova et al. 2013). These data may show that enhanced activity of p53 can mediate similar phenotypic effects compared with activation of native $\mathrm{p} 53$ by telomere dysfunction.

\section{TELOMERASE IS UP-REGULATED IN MANY HUMAN CANCERS THROUGH RECURRENT NONCODING MUTATIONS IN THE TERT PROMOTER}

Telomerase reactivation is a hallmark of carcinogenesis, and the vast majority ( $\sim 90 \%)$ of human tumors have telomerase activity. Recent findings show that many human cancer types show highly recurrent mutations in the TERT promoter (Horn et al. 2013; Huang et al. 2013). One of two positions in the TERT promoter is mutated in $21 \%$ of medulloblastomas, $83 \%$ of primary glioblastomas, $66 \%$ of urothelial carcinomas of the bladder, $47 \%$ of hepatocellular carcinomas, and $71 \%$ of melanomas, making these mutations the most common noncoding mutation in cancer discovered thus far (Killela et al. 2013; Kinde et al. 2013; Weinhold et al. 2014). Consistent with an activating role, the mutations are associated with increased TERT expression, telomerase activity, and telomere length (Weinhold et al. 2014; Borah et al. 2015). Microdissection and sequencing of primary human melanomas revealed that the TERT-promoter mutations were absent in benign lesions but present in a majority $(77 \%)$ of intermediate lesions, suggesting that TERT upregulation is a relatively early event in melanoma (Shain et al. 2015).

The two somatic mutations, G228A and G250A, generate an identical 11 base pair sequence in the promoter region that creates a de novo binding site for the E26 transformation specific (ETS) transcription factor GABPA (Bell et al. 2015). Binding of GABPA to the mutant, but not the wild-type TERT promoter can activate TERT expression. This is concurrent with a switch to active chromatin marks in the TERT promoter of the mutated allele (Stern et al. 2015). Because of their highly recurrent status, it is clear that up-regulation of TERT via its transcription is extremely advantageous to cancer cells. How the TERT-promoter mutations cooperate with other common mutations in cancer, such as those in p53, remains to be studied.

\section{CONCLUSIONS}

In human cells and in mouse models, the tumor suppressor p53 is critical for the checkpoint arrest and apoptosis in response to damage signaling from dysfunctional telomeres. This $\mathrm{p} 53$ response limits the growth of primary cells in culture but also enables p53 to suppress tumorigenesis in vivo in the context of critically short telomeres. In people with germline mutations in the telomerase pathway, telomere dysfunction 
leads to tissue failure in DC and related telomere biology disorders. In this context, p53 likely serves an important role in contributing to these phenotypes by culling progenitor cells from affected tissues. Indeed, in the absence of p53, dysfunctional telomeres are able to accelerate tumorigenesis by catalyzing chromosome fusion-bridge-breakage cycles. Telomerase upregulation is a key, rate-limiting step in tumorigenesis as evidenced by the highly recurrent mutations in the TERT promoter. These data support a model in which telomere shortening early in tumorigenesis engages p53-dependent checkpoints limiting tumor maturation. Inactivating mutations in the p53 pathway and activating mutations in the TERT promoter may be critical in evading these senescence and crisis responses and enabling tumor progression.

\section{ACKNOWLEDGMENTS}

C.M.R. is supported by Medical Scientist Training Program Grant GM007365. We acknowledge support from the National Cancer Institute CA197563.

\section{REFERENCES}

Abreu E, Aritonovska E, Reichenbach P, Cristofari G, Culp B, Terns RM, Lingner J, Terns MP. 2010. TIN2-tethered TPP1 recruits human telomerase to telomeres in vivo. Mol Cell Biol 30: 2971-2982.

Alter BP, Giri N, Savage SA, Rosenberg PS. 2009. Cancer in dyskeratosis congenita. Blood 113: 6549-6557.

Anderson BH, Kasher PR, Mayer J, Szynkiewicz M, Jenkinson EM, Bhaskar SS, Urquhart JE, Daly SB, Dickerson JE, O'Sullivan J, et al. 2012. Mutations in CTC1, encoding conserved telomere maintenance component 1, cause Coats plus. Nat Genet 44: 338-342.

Armanios M, Blackburn EH. 2012. The telomere syndromes. Nat Rev Genet 13: 693-704.

Armanios M, Chen JL, Chang YP, Brodsky RA, Hawkins A, Griffin CA, Eshleman JR, Cohen AR, Chakravarti A, Hamosh A, et al. 2005. Haploinsufficiency of telomerase reverse transcriptase leads to anticipation in autosomal dominant dyskeratosis congenita. Proc Natl Acad Sci 102: 15960-15964.

Armanios MY, Chen JJ, Cogan JD, Alder JK, Ingersoll RG, Markin C, Lawson WE, Xie M, Vulto I, Phillips JA 3rd, et al. 2007. Telomerase mutations in families with idiopathic pulmonary fibrosis. N Engl J Med 356: 1317- 1326.

Artandi SE, Chang S, Lee SL, Alson S, Gottlieb GJ, Chin L, DePinho RA. 2000. Telomere dysfunction promotes non-reciprocal translocations and epithelial cancers in mice. Nature 406: 641-645.

Ballew BJ, Yeager M, Jacobs K, Giri N, Boland J, Burdett L, Alter BP, Savage SA. 2013. Germline mutations of regulator of telomere elongation helicase 1, RTEL1, in dyskeratosis congenita. Hum Genet 132: 473-480.

Baumann P, Cech TR. 2001. Pot1, the putative telomere end-binding protein in fission yeast and humans. Science 292: $1171-1175$.

Bell RJ, Rube HT, Kreig A, Mancini A, Fouse SD, Nagarajan RP, Choi S, Hong C, He D, Pekmezci M, et al. 2015. Cancer. The transcription factor GABP selectively binds and activates the mutant TERT promoter in cancer. Science 348: 1036-1039.

Blackburn EH, Gall JG. 1978. A tandemly repeated sequence at the termini of the extrachromosomal ribosomal RNA genes in Tetrahymena. J Mol Biol 120: 33-53.

Blasco MA, Lee HW, Hande MP, Samper E, Lansdorp PM, DePinho RA, Greider CW. 1997. Telomere shortening and tumor formation by mouse cells lacking telomerase RNA. Cell 91: 25-34.

Bodnar AG, Ouellette M, Frolkis M, Holt SE, Chiu CP, Morin GB, Harley CB, Shay JW, Lichtsteiner S, Wright WE. 1998. Extension of life-span by introduction of telomerase into normal human cells. Science 279: 349-352.

Borah S, Xi L, Zaug AJ, Powell NM, Dancik GM, Cohen SB, Costello JC, Theodorescu D, Cech TR. 2015. Cancer. TERT promoter mutations and telomerase reactivation in urothelial cancer. Science 347: 1006-1010.

Brown JP, Wei W, Sedivy JM. 1997. Bypass of senescence after disruption of p21CIP1/WAF1 gene in normal diploid human fibroblasts. Science 277: 831-834.

Calado RT, Brudno J, Mehta P, Kovacs JJ, Wu C, Zago MA, Chanock SJ, Boyer TD, Young NS. 2011. Constitutional telomerase mutations are genetic risk factors for cirrhosis. Hepatology 53: 1600-1607.

Celli GB, de Lange T. 2005. DNA processing is not required for ATM-mediated telomere damage response after TRF2 deletion. Nat Cell Biol 7: 712-718.

Cesare AJ, Hayashi MT, Crabbe L, Karlseder J. 2013. The telomere deprotection response is functionally distinct from the genomic DNA damage response. Mol Cell 51: $141-155$.

Chen LY, Majerska J, Lingner J. 2013. Molecular basis of telomere syndrome caused by CTC1 mutations. Genes Dev 27: 2099-2108.

Chin L, Artandi SE, Shen Q, Tam A, Lee SL, Gottlieb GJ, Greider CW, DePinho RA. 1999. p53 deficiency rescues the adverse effects of telomere loss and cooperates with telomere dysfunction to accelerate carcinogenesis. Cell 97: 527-538.

Counter CM, Avilion AA, LeFeuvre CE, Stewart NG, Greider CW, Harley CB, Bacchetti S. 1992. Telomere shortening associated with chromosome instability is arrested in immortal cells which express telomerase activity. EMBO J 11: $1921-1929$.

d'Adda di Fagagna F, Reaper PM, Clay-Farrace L, Fiegler H, Carr P, Von Zglinicki T, Saretzki G, Carter NP, Jackson SP. 2003. A DNA damage checkpoint response in telomereinitiated senescence. Nature 426: 194-198. 
C.M. Roake and S.E. Artandi

Davoli T, de Lange T. 2012. Telomere-driven tetraploidization occurs in human cells undergoing crisis and promotes transformation of mouse cells. Cancer Cell 21: 765-776.

Davoli T, Denchi EL, de Lange T. 2010. Persistent telomere damage induces bypass of mitosis and tetraploidy. Cell 141: 81-93.

de Lange T. 2005. Shelterin: The protein complex that shapes and safeguards human telomeres. Genes Dev 19: 2100-2110.

Denchi EL, de Lange T. 2007. Protection of telomeres through independent control of ATM and ATR by TRF2 and POT1. Nature 448: 1068-1071.

Dhanraj S, Gunja SM, Deveau AP, Nissbeck M, Boonyawat B, Coombs AJ, Renieri A, Mucciolo M, Marozza A, Buoni S, et al. 2015. Bone marrow failure and developmental delay caused by mutations in poly(A)-specific ribonuclease (PARN). J Med Genet 52: 738-748.

Doksani Y, Wu JY, de Lange T, Zhuang X. 2013. Superresolution fluorescence imaging of telomeres reveals TRF2-dependent T-loop formation. Cell 155: 345-356.

Else T, Hammer G. 2009. Genetic p53deficiency partially rescues the adrenocortical dysplasia (ACD) phenotype at the expense of increased tumorigenesis. Cancer Cell 15: $465-476$.

Feldser DM, Greider CW. 2007. Short telomeres limit tumor progression in vivo by inducing senescence. Cancer Cell 11: 461-469.

Gonzalez-Suarez E, Samper E, Flores JM, Blasco MA. 2000. Telomerase-deficient mice with short telomeres are resistant to skin tumorigenesis. Nat Genet 26: 114-117.

Greenberg RA, Chin L, Femino A, Lee KH, Gottlieb GJ, Singer RH, Greider CW, DePinho RA. 1999. Short dysfunctional telomeres impair tumorigenesis in the INK4a $\Delta^{2 / 3}$ cancer-prone mouse. Cell 97: 515-525.

Greider CW, Blackburn EH. 1985. Identification of a specific telomere terminal transferase activity in Tetrahymena extracts. Cell 43: 405-413.

Griffith JD, Comeau L, Rosenfield S, Stansel RM, Bianchi A, Moss H, de Lange T. 1999. Mammalian telomeres end in a large duplex loop. Cell 97: 503-514.

Hara E, Tsurui H, Shinozaki A, Nakada S, Oda K. 1991. Cooperative effect of antisense- $\mathrm{Rb}$ and antisense-p53 oligomers on the extension of life span in human diploid fibroblasts, TIG-1. Biochem Biophys Res Commun 179: $528-534$.

Harel I, Benayoun BA, Machado B, Singh PP, Hu CK, Pech MF, Valenzano DR, Zhang E, Sharp SC, Artandi SE, et al. 2015. A platform for rapid exploration of aging and diseases in a naturally short-lived vertebrate. Cell 160: 1013-1026.

Harley CB, Futcher AB, Greider CW. 1990. Telomeres shorten during ageing of human fibroblasts. Nature 345: $458-460$.

Hartmann D, Srivastava U, Thaler M, Kleinhans KN, N'Kontchou G, Scheffold A, Bauer K, Kratzer RF, Kloos N, Katz SF, et al. 2011. Telomerase gene mutations are associated with cirrhosis formation. Hepatology 53: $1608-1617$.

Hayflick L, Moorhead PS. 1961. The serial cultivation of human diploid cell strains. Exp Cell Res 25: 585-621.
Henriques CM, Carneiro MC, Tenente IM, Jacinto A, Ferreira MG. 2013. Telomerase is required for zebrafish lifespan. PLoS Genet 9: e1003214.

Herrera E, Samper E, Martin-Caballero J, Flores JM, Lee HW, Blasco MA. 1999. Disease states associated with telomerase deficiency appear earlier in mice with short telomeres. EMBO J 18: 2950-2960.

Hockemeyer D, Sfeir AJ, Shay JW, Wright WE, de Lange T. 2005. POT1 protects telomeres from a transient DNA damage response and determines how human chromosomes end. EMBO J 24: 2667-2678.

Hockemeyer D, Daniels JP, Takai H, de Lange T. 2006. Recent expansion of the telomeric complex in rodents: Two distinct POT1 proteins protect mouse telomeres. Cell 126: $63-77$.

Hockemeyer D, Palm W, Else T, Daniels JP, Takai KK, Ye JZ, Keegan CE, de Lange T, Hammer GD. 2007. Telomere protection by mammalian Pot1 requires interaction with Tpp1. Nat Struct Mol Biol 14: 754-761.

Horn S, Figl A, Rachakonda PS, Fischer C, Sucker A, Gast A, Kadel S, Moll I, Nagore E, Hemminki K, et al. 2013. TERT promoter mutations in familial and sporadic melanoma. Science 339: 959-961.

Huang FW, Hodis E, Xu MJ, Kryukov GV, Chin L, Garraway LA. 2013. Highly recurrent TERT promoter mutations in human melanoma. Science 339: 957-959.

Kabir S, Hockemeyer D, de Lange T. 2014. TALEN gene knockouts reveal no requirement for the conserved human shelterin protein Rap1 in telomere protection and length regulation. Cell Rep 9: 1273-1280.

Kamijo T, Zindy F, Roussel MF, Quelle DE, Downing JR, Ashmun RA, Grosveld G, Sherr CJ. 1997. Tumor suppression at the mouse INK4a locus mediated by the alternative reading frame product p19ARF. Cell 91: 649-659.

Keegan CE, Hutz JE, Else T, Adamska M, Shah SP, Kent AE, Howes JM, Beamer WG, Hammer GD. 2005. Urogenital and caudal dysgenesis in adrenocortical dysplasia (ACD) mice is caused by a splicing mutation in a novel telomeric regulator. Hum Mol Genet 14: 113-123.

Khoo CM, Carrasco DR, Bosenberg MW, Paik JH, Depinho RA. 2007. Ink4a/Arf tumor suppressor does not modulate the degenerative conditions or tumor spectrum of the telomerase-deficient mouse. Proc Natl Acad Sci 104: 3931-3936.

Killela PJ, Reitman ZJ, Jiao Y, Bettegowda C, Agrawal N, Diaz LA Jr, Friedman AH, Friedman H, Gallia GL, Giovanella BC, et al. 2013. TERT promoter mutations occur frequently in gliomas and a subset of tumors derived from cells with low rates of self-renewal. Proc Natl Acad Sci 110: 6021-6026.

Kim NW, Piatyszek MA, Prowse KR, Harley CB, West MD, Ho PL, Coviello GM, Wright WE, Weinrich SL, Shay JW. 1994. Specific association of human telomerase activity with immortal cells and cancer. Science 266: 2011-2015.

Kim SH, Kaminker P, Campisi J. 1999. TIN2, a new regulator of telomere length in human cells. Nat Genet 23: 405412.

Kinde I, Munari E, Faraj SF, Hruban RH, Schoenberg M, Bivalacqua T, Allaf M, Springer S, Wang Y, Diaz LA Jr, et al. 2013. TERT promoter mutations occur early in urothelial neoplasia and are biomarkers of early disease and disease recurrence in urine. Cancer Res 73: 7162-7167. 
Kipling D, Cooke HJ. 1990. Hypervariable ultra-long telomeres in mice. Nature 347: 400-402.

Knight SW, Heiss NS, Vulliamy TJ, Greschner S, Stavrides G, Pai GS, Lestringant G, Varma N, Mason PJ, Dokal I, et al. 1999. X-linked dyskeratosis congenita is predominantly caused by missense mutations in the DKC1 gene. Am J Hum Genet 65: 50-58.

Kocak H, Ballew BJ, Bisht K, Eggebeen R, Hicks BD, Suman S, O’Neil A, Giri N, Maillard I, Alter BP, et al. 2014. Hoyeraal-Hreidarsson syndrome caused by a germline mutation in the TEL patch of the telomere protein TPP1. Genes Dev 28: 2090-2102.

Lee HW, Blasco MA, Gottlieb GJ, Horner JW, Greider CW, DePinho RA. 1998. Essential role of mouse telomerase in highly proliferative organs. Nature 392: 569-574.

Li B, Oestreich S, de Lange T. 2000. Identification of human Rap1: Implications for telomere evolution. Cell 101: 471-483.

Lingner J, Hughes TR, Shevchenko A, Mann M, Lundblad V, Cech TR. 1997. Reverse transcriptase motifs in the catalytic subunit of telomerase. Science 276: 561-567.

Liu D, Safari A, O'Connor MS, Chan DW, Laegeler A, Qin J, Songyang Z. 2004. PTOP interacts with POT1 and regulates its localization to telomeres. Nat Cell Biol 6: $673-680$.

Loayza D, de Lange T. 2003. POT1 as a terminal transducer of TRF1 telomere length control. Nature 424: 10131018.

Lundblad V, Blackburn EH. 1993. An alternative pathway for yeast telomere maintenance rescues est1- senescence. Cell 73: 347-360.

Maciejowski J, Li Y, Bosco N, Campbell PJ, de Lange T. 2015. Chromothripsis and kataegis induced by telomere crisis. Cell 163: 1641-1654.

Martinez P, Thanasoula M, Munoz P, Liao C, Tejera A, McNees C, Flores JM, Fernandez-Capetillo O, Tarsounas M, Blasco MA. 2009. Increased telomere fragility and fusions resulting from TRF1 deficiency lead to degenerative pathologies and increased cancer in mice. Genes Dev 23: 2060-2075.

Meyerson M, Counter CM, Eaton EN, Ellisen LW, Steiner P, Caddle SD, Ziaugra L, Beijersbergen RL, Davidoff MJ, Liu Q, et al. 1997. hEST2, the putative human telomerase catalytic subunit gene, is up-regulated in tumor cells and during immortalization. Cell 90: 785-795.

Mitchell JR, Wood E, Collins K. 1999. A telomerase component is defective in the human disease dyskeratosis congenita. Nature 402: 551-555.

Moon DH, Segal M, Boyraz B, Guinan E, Hofmann I, Cahan P, Tai AK, Agarwal S. 2015. Poly(A)-specific ribonuclease (PARN) mediates $3^{\prime}$-end maturation of the telomerase RNA component. Nat Genet 47: 1482-1488.

Nakamura TM, Morin GB, Chapman KB, Weinrich SL, Andrews WH, Lingner J, Harley CB, Cech TR. 1997. Telomerase catalytic subunit homologs from fission yeast and human. Science 277: 955-959.

Nandakumar J, Bell CF, Weidenfeld I, Zaug AJ, Leinwand LA, Cech TR. 2012. The TEL patch of telomere protein TPP1 mediates telomerase recruitment and processivity. Nature 492: 285-289.
O'Hagan RC, Chang S, Maser RS, Mohan R, Artandi SE, Chin L, DePinho RA. 2002. Telomere dysfunction provokes regional amplification and deletion in cancer genomes. Cancer Cell 2: 149-155.

Olovnikov AM. 1973. A theory of marginotomy. The incomplete copying of template margin in enzymic synthesis of polynucleotides and biological significance of the phenomenon. J Theor Biol 41: 181-190.

Palm W, de Lange T. 2008. How shelterin protects mammalian telomeres. Annu Rev Genet 41: 301-334.

Rudolph KL, Chang S, Lee HW, Blasco M, Gottlieb GJ, Greider C, DePinho RA. 1999. Longevity, stress response, and cancer in aging telomerase-deficient mice. Cell 96: 701-712.

Rudolph KL, Millard M, Bosenberg MW, DePinho RA. 2001. Telomere dysfunction and evolution of intestinal carcinoma in mice and humans. Nat Genet 28: 155-159.

Savage SA, Giri N, Baerlocher GM, Orr N, Lansdorp PM, Alter BP. 2008. TINF2, a component of the shelterin telomere protection complex, is mutated in dyskeratosis congenita. Am J Hum Genet 82: 501-509.

Serrano M, Lee H, Chin L, Cordon-Cardo C, Beach D, DePinho RA. 1996. Role of the INK4a locus in tumor suppression and cell mortality. Cell 85: 27-37.

Sexton AN, Regalado SG, Lai CS, Cost GJ, O’Neil CM, Urnov FD, Gregory PD, Jaenisch R, Collins K, Hockemeyer D. 2014. Genetic and molecular identification of three human TPP1 functions in telomerase action: Recruitment, activation, and homeostasis set point regulation. Genes Dev 28: 1885-1899.

Sfeir A, Kosiyatrakul ST, Hockemeyer D, MacRae SL, Karlseder J, Schildkraut CL, de Lange T. 2009. Mammalian telomeres resemble fragile sites and require TRF1 for efficient replication. Cell 138: 90-103.

Sfeir A, Kabir S, van Overbeek M, Celli GB, de Lange T. 2010. Loss of Rap1 induces telomere recombination in the absence of NHEJ or a DNA damage signal. Science 327: 1657-1661.

Shain AH, Yeh I, Kovalyshyn I, Sriharan A, Talevich E, Gagnon A, Dummer R, North J, Pincus L, Ruben B, et al. 2015. The genetic evolution of melanoma from precursor lesions. N Engl J Med 373: 1926-1936.

Shay JW, Pereira-Smith OM, Wright WE. 1991. A role for both RB and p53 in the regulation of human cellular senescence. Exp Cell Res 196: 33-39.

Simeonova I, Jaber S, Draskovic I, Bardot B, Fang M, Bouarich-Bourimi R, Lejour V, Charbonnier L, Soudais C, Bourdon JC, et al. 2013. Mutant mice lacking the p53 C-terminal domain model telomere syndromes. Cell Rep 3: $2046-2058$

Smogorzewska A, van Steensel B, Bianchi A, Oelmann S, Schaefer MR, Schnapp G, de Lange T. 2000. Control of human telomere length by TRF1 and TRF2. Mol Cell Biol 20: $1659-1668$.

Smogorzewska A, Karlseder J, Holtgreve-Grez H, Jauch A, de Lange T. 2002. DNA ligase IV-dependent NHEJ of deprotected mammalian telomeres in $\mathrm{G}_{1}$ and $\mathrm{G}_{2}$. Curr Biol 12: 1635-1644.

Stern JL, Theodorescu D, Vogelstein B, Papadopoulos N, Cech TR. 2015. Mutation of the TERT promoter, switch 
C.M. Roake and S.E. Artandi

to active chromatin, and monoallelic TERT expression in multiple cancers. Genes Dev 29: 2219-2224.

Stuart BD, Choi J, Zaidi S, Xing C, Holohan B, Chen R, Choi M, Dharwadkar P, Torres F, Girod CE, et al. 2015. Exome sequencing links mutations in PARN and RTEL1 with familial pulmonary fibrosis and telomere shortening. Nat Genet 47: 512-517.

Takai H, Smogorzewska A, de Lange T. 2003. DNA damage foci at dysfunctional telomeres. Curr Biol 13: 1549-1556.

Vannier JB, Sandhu S, Petalcorin MI, Wu X, Nabi Z, Ding H, Boulton SJ. 2013. RTEL1 is a replisome-associated helicase that promotes telomere and genome-wide replication. Science 342: 239-242.

van Steensel B, de Lange T. 1997. Control of telomere length by the human telomeric protein TRF1. Nature 385: 740743.

van Steensel B, Smogorzewska A, de Lange T. 1998. TRF2 protects human telomeres from end-to-end fusions. Cell 92: 401-413.

Venteicher AS, Abreu EB, Meng Z, McCann KE, Terns RM, Veenstra TD, Terns MP, Artandi SE. 2009. A human telomerase holoenzyme protein required for Cajal body localization and telomere synthesis. Science 323: 644-648.

Vlangos CN, O'Connor BC, Morley MJ, Krause AS, Osawa GA, Keegan CE. 2009. Caudal regression in adrenocortical dysplasia (ACD) mice is caused by telomere dysfunction with subsequent p53-dependent apoptosis. Dev Biol 334: 418-428.

Vulliamy T, Marrone A, Goldman F, Dearlove A, Bessler M, Mason PJ, Dokal I. 2001. The RNA component of telomerase is mutated in autosomal dominant dyskeratosis congenita. Nature 413: 432-435.

Vulliamy T, Marrone A, Szydlo R, Walne A, Mason PJ, Dokal I. 2004. Disease anticipation is associated with progressive telomere shortening in families with dyskeratosis congenita due to mutations in TERC. Nat Genet 36: 447-449.

Vulliamy T, Beswick R, Kirwan M, Marrone A, Digweed M, Walne A, Dokal I. 2008. Mutations in the telomerase component NHP2 cause the premature ageing syndrome dyskeratosis congenita. Proc Natl Acad Sci 105: $8073-$ 8078.

Walne AJ, Vulliamy T, Marrone A, Beswick R, Kirwan M, Masunari Y, Al-Qurashi FH, Aljurf M, Dokal I. 2007. Genetic heterogeneity in autosomal recessive dyskeratosis congenita with one subtype due to mutations in the telomerase-associated protein NOP10. Hum Mol Genet 16: $1619-1629$.

Walne AJ, Vulliamy T, Kirwan M, Plagnol V, Dokal I. 2013. Constitutional mutations in RTEL1 cause severe dyskeratosis congenita. Am J Hum Genet 92: 448-453.
Wang F, Podell ER, Zaug AJ, Yang Y, Baciu P, Cech TR, Lei M. 2007. The POT1-TPP1 telomere complex is a telomerase processivity factor. Nature 445: 506-510.

Watson JD. 1972. Origin of concatemeric T7 DNA. Nat New Biol 239: 197-201.

Weinhold N, Jacobsen A, Schultz N, Sander C, Lee W. 2014. Genome-wide analysis of noncoding regulatory mutations in cancer. Nat Genet 46: 1160-1165.

Wong KK, Chang S, Weiler SR, Ganesan S, Chaudhuri J, Zhu C, Artandi SE, Rudolph KL, Gottlieb GJ, Chin L, et al. 2000. Telomere dysfunction impairs DNA repair and enhances sensitivity to ionizing radiation. Nat Genet 26: $85-88$.

Wu L, Multani AS, He H, Cosme-Blanco W, Deng Y, Deng JM, Bachilo O, Pathak S, Tahara H, Bailey SM, et al. 2006. Pot1 deficiency initiates DNA damage checkpoint activation and aberrant homologous recombination at telomeres. Cell 126: 49-62.

Xin H, Liu D, Wan M, Safari A, Kim H, Sun W, O'Connor MS, Songyang Z. 2007. TPP1 is a homologue of ciliate TEBP- $\beta$ and interacts with POT1 to recruit telomerase. Nature 445: 559-562.

Yamaguchi H, Baerlocher GM, Lansdorp PM, Chanock SJ, Nunez O, Sloand E, Young NS. 2003. Mutations of the human telomerase RNA gene (TERC) in aplastic anemia and myelodysplastic syndrome. Blood 102: 916-918.

Yamaguchi H, Calado RT, Ly H, Kajigaya S, Baerlocher GM, Chanock SJ, Lansdorp PM, Young NS. 2005. Mutations in TERT, the gene for telomerase reverse transcriptase, in aplastic anemia. N Engl J Med 352: 1413-1424.

Ye JZ, Hockemeyer D, Krutchinsky AN, Loayza D, Hooper SM, Chait BT, de Lange T. 2004. POT1-interacting protein PIP1: A telomere length regulator that recruits POT1 to the TIN2/TRF1 complex. Genes Dev 18: 1649-1654.

Yeung F, Ramirez CM, Mateos-Gomez PA, Pinzaru A, Ceccarini G, Kabir S, Fernandez-Hernando C, Sfeir A. 2013. Nontelomeric role for Rap1 in regulating metabolism and protecting against obesity. Cell Rep 3: 1847-1856.

Yu GL, Bradley JD, Attardi LD, Blackburn EH. 1990. In vivo alteration of telomere sequences and senescence caused by mutated Tetrahymena telomerase RNAs. Nature 344: $126-132$.

Zhong F, Savage SA, Shkreli M, Giri N, Jessop L, Myers T, Chen R, Alter BP, Artandi SE. 2011. Disruption of telomerase trafficking by TCAB1 mutation causes dyskeratosis congenita. Genes Dev 25: 11-16.

Zhong FL, Batista LF, Freund A, Pech MF, Venteicher AS, Artandi SE. 2012. TPP1 OB-fold domain controls telomere maintenance by recruiting telomerase to chromosome ends. Cell 150: 481-494. 


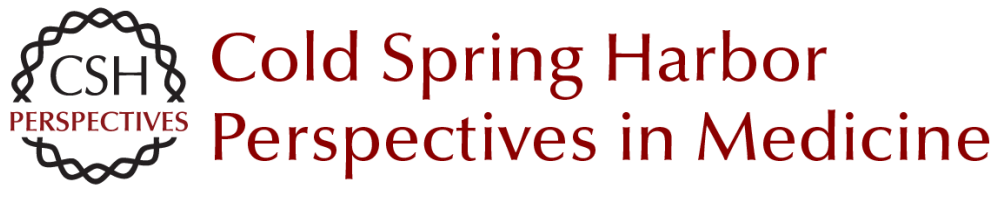

\title{
Control of Cellular Aging, Tissue Function, and Cancer by p53 Downstream of Telomeres
}

\author{
Caitlin M. Roake and Steven E. Artandi
}

Cold Spring Harb Perspect Med 2017; doi: 10.1101/cshperspect.a026088 originally published online March 13, 2017

\section{Subject Collection The p53 Protein}

Targeting the MDM2-p53 Protein-Protein Interaction for New Cancer Therapy: Progress and Challenges Shaomeng Wang, Yujun Zhao, Angelo Aguilar, et al.

Structural Evolution and Dynamics of the p53 Proteins Giovanni Chillemi, Sebastian Kehrloesser, Francesca Bernassola, et al.

Exploiting the p53 Pathway for Therapy Chit Fang Cheok and David Philip Lane

The Regulation of Cellular Functions by the p53 Protein: Cellular Senescence Crystal A. Tonnessen-Murray, Guillermina Lozano and James $G$. Jackson

The Transactivation Domains of the p53 Protein Nitin Raj and Laura D. Attardi

The Evolution of the Ribosomal Protein-MDM2p53 Pathway

Chad Deisenroth, Derek A. Franklin and Yanping Zhang

Somatic TP53 Mutations in the Era of Genome Sequencing Pierre Hainaut and Gerd P. Pfeifer

The Paradox of p53: What, How, and Why? Yael Aylon and Moshe Oren
Control of Cellular Aging, Tissue Function, and Cancer by p53 Downstream of Telomeres Caitlin M. Roake and Steven E. Artandi

Inherited TP53 Mutations and the Li -Fraumeni Syndrome

Tanya Guha and David Malkin

\section{TP53 Mutations in Hypodiploid Acute Lymphoblastic Leukemia \\ Evan Q. Comeaux and Charles G. Mullighan \\ Transcriptional Regulation by Wild-Type and \\ Cancer-Related Mutant Forms of p53 \\ Neil T. Pfister and Carol Prives}

The Inherited p53 Mutation in the Brazilian

Population

Maria Isabel Achatz and Gerard P. Zambetti

TP53 Mutations in Breast and Ovarian Cancer Laxmi Silwal-Pandit, Anita Langerød and Anne-Lise Børresen-Dale

p53 and the Carcinogenicity of Chronic Inflammation

Andrei V. Gudkov and Elena A. Komarova

Oncogenic Mutant p53 Gain of Function

Nourishes the Vicious Cycle of Tumor

Development and Cancer Stem-Cell Formation

Yoav Shetzer, Alina Molchadsky and Varda Rotter

For additional articles in this collection, see http://perspectivesinmedicine.cshlp.org/cgi/collection/ 